\title{
PRIMJENA METODE KONSTANTNIH TRŽIŠNIH UDJELA NA IZVOZ USLUŽNOGA SEKTORA VISOKE DODANE VRIJEDNOSTI REPUBLIKE HRVATSKE NA TRŽIŠTE EUROPSKE UNIJE
}

U ovome radu po prvi puta se analizira promjena relativnog položaja izvoza uslužnoga sektora visoke dodane vrijednosti Republike Hrvatske na tržište Europske unije, u razdoblju od 2008. do 2012. godine, primjenom metode konstantnih tržišnih udjela, koja omogućuje utvrđivanje učinaka promjena tržišnog udjela neke zemlje. Promjena tržišnog udjela raščlanjuje se na strukturni učinak, koji pokazuje koliko na promjenu tržišnog udjela utječe sama struktura izvoza prema pojedinim uslugama (uslužna orijentacija), odnosno izvoznim tržištima (geografska orijentacija) te učinak konkurentnosti koji obuhvaća sve ostale čimbenike koji mogu utjecati na konkurentnost nekih usluga na određenom tržištu i posljedično na njihov tržišni udio. Rezultati provedenog istraživanja pokazuju da je porast udjela hrvatskog izvoza usluga visoke dodane vrijednosti na tržište Europske unije u razdoblju od 2008. do 2012. godine poglavito posljedica učinka konkurentnosti.

* Dr. sc. Z. Lacković Vincek, poslijedoktorandica, Sveučilište u Zagrebu, Fakultet organizacije i informatike Varaždin (E-mail: zlackovi@foi.hr).

${ }^{* *}$ Dr. sc. V. Bilas, redovita profesorica, Sveučilište u Zagrebu, Ekonomski fakultet (E-mail: vbilas@efzg.hr).

*** Dr. sc. M. Bošnjak, docent, Sveučilište u Zagrebu, Ekonomski fakultet (E-mail: mbosnjak1@ efzg.hr).

Rad se temelji na rezultatima doktorske disertacije obranjene u akademskoj godini 2016./2017. te je prilagođen objavi u časopisu kako bi se rezultati istraživanja stavili na raspolaganje široj znanstvenoj i stručnoj javnosti.

Rad je primljen u uredništvo 15.02.2018. godine, a prihvaćen je za objavu 15.09.2018. godine. 
Ključne riječi: izvoz, usluge, dodana vrijednost, metoda konstantnih tržišnih udjela

\section{Uvod}

Međunarodna trgovina uslugama se u posljednjih tridesetak godina, koliko se ozbiljnije prate statistički podaci vezani uz uslužne djelatnosti, povećavala većom dinamikom od razmjene roba, na što upućuju i podaci United Nations Conference on Trade and Development ([UNCTAD], 2015), sukladno kojima je 1980. godine vrijednost svjetskog izvoza roba bila 2,050 milijardi USD, a vrijednost svjetskog izvoza usluga 395 milijuna USD, dok je 2012. godine vrijednost svjetskog izvoza roba bila 18,545 milijardi USD, a vrijednost svjetskog izvoza usluga 4,786 milijardi USD. Rast svjetskog izvoza usluga ostvaren je zbog nekoliko razloga: rasta dohotka svjetskog stanovništva, izraženog rasta inozemnih izravnih ulaganja upravo u uslužne djelatnosti, liberalizacije međunarodne trgovine uslugama, tehničkog napretka, procesa privatizacije, unifikacije međunarodnog trgovinskog prava, konvertibilnosti većeg broja valuta i povećanja broja zemalja u svijetu.

U ovom se radu posebna pažnja posvećuje promatranju važnih, ali vrlo malo istraživanih djelatnosti u kontekstu doprinosa izvozu usluga - djelatnosti uslužnog sektora visoke dodane vrijednosti. Riječ je o sektoru visoke tehnološke razvijenosti, koji ima multiplikativni učinak na druge sektore gospodarstva. Također, u kontekstu izvoza usluga Republike Hrvatske na tržište Europske unije, navedeni sektor nije istraživan na predloženi način, čime su stvoreni dodatni preduvjeti ostvarivanja znanstvenog doprinosa ovog rada.

Cilj rada je analiziranjem promjena relativnog položaja izvoza uslužnog sektora visoke dodane vrijednosti Republike Hrvatske na tržište Europske unije utvrditi uzroke promjena udjela izvoza uslužnog sektora visoke dodane vrijednosti Republike Hrvatske na tržište Europske unije, u vremenskom razdoblju od 2008. do 2012. godine. Istraživačka hipoteza glasi: Promjene tržišnog udjela izvoza uslužnog sektora visoke dodane vrijednosti Republike Hrvatske na tržište Europske unije uzrokovane su u najvećoj mjeri učinkom konkurentnosti. Empirijskom provjerom ove hipoteze donose se zaključci u kojoj je mjeri na promjenu udjela izvoza uslužnog sektora visoke dodane vrijednosti Republike Hrvatske na tržište Europske unije utjecala struktura i orijentacija izvoza usluga sektora visoke dodane vrijednosti, odnosno jesu li hrvatski izvoznici usluga sektora visoke dodane vrijednosti bili manje ili više uspješni od konkurenata u odabiru brzo rastućih usluga i tržišta ili se pak razlog njihove promjene dominantno krije u konkurentnosti u širem smislu. 
Podaci o razini izvoza usluga visoke dodane vrijednosti Republike Hrvatske na tržište Europske unije raspoloživi su za razdoblje od 2004. do 2016. godine, međutim istraživanje se provodi do kraja 2012. godine kako bi se obuhvatilo samo razdoblje u kojem Republika Hrvatska nije bila članica Europske unije. Osnovni pokazatelji nisu podložni promjenama u kratkom razdoblju te se stoga rezultati istraživanja mogu smatrati relevantnima i za naredne godine.

Uslužni sektor visoke dodane vrijednosti iskazuje horizontalnu važnost u utjecaju na rast produktivnosti i razvoj ukupnoga gospodarstva kroz prelijevanje znanja, ideja i rasta efikasnosti unutar tradicionalnih sektora gospodarstva, kao što su poljoprivreda, prerađivačka industrija, transport, turizam i građevinarstvo, čime im omogućuju pomicanje na više razine u lancu dodane vrijednosti. Navedeni je sektor ostvarivao porast broja zaposlenih i u razdoblju nepovoljnih makroekonomskih prilika, kako u Republici Hrvatskoj, tako i u zemljama članicama Europske unije, zbog čega je za očekivati da će doći do još bržeg rasta i razvoja u povoljnijim uvjetima. Od svih područja djelatnosti koja čine uslužni sektor, Europska komisija ističe kako najveći udio u unutarnjoj trgovini uslugama na tržištu Europske unije ostvaruje uslužni sektor visoke dodane vrijednosti, tj. $22 \%$ u 2012. godini. Prema podacima Eurostata (2016a), djelatnosti koje čine uslužni sektor visoke dodane vrijednosti u 2012. godini činile su 11,7\% BDP-a i 12,6\% zaposlenosti u Europskoj uniji.

Obuhvat djelatnosti uslužnog sektora visoke dodane vrijednosti, najčešce korišten i u međunarodnoj praksi, prema statističkoj klasifikaciji ekonomskih djelatnosti Europske komisije NACE Rev. 2. i Republike Hrvatske NKD 2007., obuhvaća djelatnosti informacija i komunikacija (djelatnost J), stručne, znanstvene i tehničke djelatnosti (djelatnost $\mathrm{M}$ ) te administrativne i pomoćne uslužne djelatnosti (djelatnost $\mathrm{N}$ ), a smatra se sektorom visoke dodane vrijednosti, jer prema navedenom obuhvatu u 2012. godini čini nešto više od jedne desetine bruto dodane vrijednosti u Republici Hrvatskoj (Državni zavod za statistiku [DZS], 2013).

Prema NKD 2007. i Nace Rev 2. klasifikaciji ekonomskih djelatnosti, odjeljci područja uslužne djelatnosti informacija i komunikacija (J) su:

- izdavačke djelatnosti,

- izdavanje softvera,

- proizvodnja filmova, videofilmova i televizijskog programa,

- djelatnosti snimanja zvučnih zapisa i izdavanja glazbenih zapisa,

- emitiranje programa,

- telekomunikacije,

- računalno programiranje, savjetovanje i djelatnosti povezane s njima te

- informacijske uslužne djelatnosti. 
Prema podacima Eurostata (2016a), odjeljak djelatnosti računalnog programiranja, savjetovanja i djelatnosti povezane s njima u EU27 sudjeluje s najvećim udjelom u realnoj bruto dodanoj vrijednosti $(39,1 \%)$ te zapošljava $47 \%$ ukupnog broja zaposlenih u djelatnosti J (2012. godine).

Odjeljci područja stručnih, znanstvenih i tehničkih djelatnosti (M) su:

- pravne i računovodstvene djelatnosti,

- upravljačke djelatnosti; savjetovanje u vezi s upravljanjem,

- arhitektonske djelatnosti i inženjerstvo; tehničko ispitivanje i analiza,

- znanstveno istraživanje i razvoj,

- promidžba (reklama i propaganda) i istraživanje tržišta,

- ostale stručne, znanstvene i tehničke djelatnosti te

- veterinarske djelatnosti.

Sukladno podacima Eurostata (2016a), pravne i računovodstvene djelatnosti u EU27 sudjeluju s najvećim udjelom u realnoj bruto dodanoj vrijednosti (29,7\% ukupne djelatnosti M), a zapošljavaju 29,5\% ukupnog broja zaposlenih u djelatnosti M (2012. godine).

Odjeljci područja administrativnih i pomoćnih uslužnih djelatnosti (N) su:

- djelatnosti iznajmljivanja i davanja u zakup (leasing),

- djelatnosti zapošljavanja,

- putničke agencije, organizatori putovanja (turoperatori) i ostale rezervacijske usluge te djelatnosti povezane s njima,

- zaštitne i istražne djelatnosti,

- usluge u vezi s upravljanjem i održavanjem zgrada te djelatnosti uređenja i održavanja krajolika te

- uredske administrativne i pomoćne djelatnosti te ostale poslovne pomoćne djelatnosti.

Prema podacima Eurostata (2016a), u EU27 odjeljak djelatnosti zapošljavanja sudjeluje s najvećim udjelom u realnoj bruto dodanoj vrijednosti (27,4\% ukupne djelatnosti N) te zapošljava 33,2\% ukupnog broja zaposlenih u djelatnosti N (2012. godine).

U tablici 1. prikazana je struktura usluga na općoj razini u Republici Hrvatskoj, sukladno NKD 2007. nacionalnoj klasifikaciji djelatnosti, odnosno udio usluga u BDP-u i zaposlenosti 2012. godine. Iz prikazanih se podataka može zaključiti kako uslužni sektor visoke dodane vrijednosti (područja djelatnosti J, M i N) u Republici Hrvatskoj 2012. godine sudjeluje s udjelom od 10,2\% u BDP-u te udjelom od 16,20\% u zaposlenosti Republike Hrvatske. 
Z. LACKOVIĆ VINCEK, V. BILAS, M. BOŠNJAK: Primjena metode konstantnih tržišnih udjela na izvoz uslužnog sektora... EKONOMSKI PREGLED, 70 (3) 351-379 (2019)

\section{Tablica 1.}

\section{UDIO USLUGA REPUBLIKE HRVATSKE U BRUTO DOMAĆEM PROIZVODU I U ZAPOSLENOSTI U 2012. GODINI, U POSTOCIMA}

\begin{tabular}{|l|c|c|}
\hline \multicolumn{1}{|c|}{ Područja NKD-a 2007. } & $\begin{array}{c}\text { Udio u BDP-u, } \\
\mathbf{u} \%\end{array}$ & $\begin{array}{c}\text { Udio u zaposlenosti } \\
\text { u uslugama, u \% }\end{array}$ \\
\hline $\begin{array}{l}\text { G Trgovina na veliko i na malo; popravak motornih } \\
\text { vozila i motocikala }\end{array}$ & 9,3 & 22,00 \\
\hline H Prijevoz i skladištenje & 3,8 & 8,05 \\
\hline $\begin{array}{l}\text { I Djelatnosti pružanja smještaja te pripreme i } \\
\text { usluživanja hrane }\end{array}$ & 3,9 & 8,96 \\
\hline J Informacije i komunikacije & 4,0 & 3,70 \\
\hline K Financijske djelatnosti i djelatnosti osiguranja & 5,8 & 4,05 \\
\hline L Poslovanje nekretninama & 9,4 & 0,69 \\
\hline M Stručne, znanstvene i tehničke djelatnosti & 4,4 & 7,80 \\
\hline N Administrativne i pomoćne uslužne djelatnosti & 1,8 & 4,70 \\
\hline O Javna uprava i obrana; obvezno socijalno osiguranje & 5,3 & 12,13 \\
\hline P Obrazovanje & 4,0 & 11,49 \\
\hline Q Djelatnosti zdravstvene zaštite i socijalne skrbi & 4,1 & 10,27 \\
\hline R Umjetnost, zabava i rekreacija & 1,3 & 2,52 \\
\hline S Ostale uslužne djelatnosti & 0,9 & 3,12 \\
\hline
\end{tabular}

Izvor: obrada autora prema DZS (2013.). Strukturne poslovne statistike, Zagreb: Državni zavod za statistiku.

Uslužni sektor visoke dodane vrijednosti i u vrijeme krize ostvarivao je rast prihoda i broja zaposlenih, no unatoč tome ne tretira se kao pokretač rasta i razvoja gospodarstva. Sukladno podacima Hrvatske narodne banke (2015) prihod od prodaje (izvoz) usluga sektora visoke dodane vrijednosti pokazuje uzlazni trend $\mathrm{u}$ većini djelatnosti u razdoblju od 2003. do 2012. godine te je iz značajnog neto uvoznika postao neto izvoznik. U 2012. godini ostvaren je prihod od prodaje usluga visoke dodane vrijednosti Republike Hrvatske na tržištu Europske unije u iznosu od 1,032 milijardi eura, što je $11 \%$ od ukupnog prihoda od prodaje svih usluga na tržištu Europske unije te godine.

Tržišni položaj izvoznika usluga visoke dodane vrijednosti Republike Hrvatske posebno je važan u kontekstu Europske unije koja je njeno najvažnije izvozno odredište. U prilog navedenome idu podaci International Trade Centra (2015), prema kojima je u 2012. godini čak 69,54\% izvoza uslužnog sektora visoke 
dodane vrijednosti iz Republike Hrvatske bilo upravo u zemlje članice Europske unije, što ih čini najvažnijim trgovinskim partnerom Republike Hrvatske u razmjeni ovih usluga.

Rad je strukturiran na sljedeći način: nakon uvodnih razmatranja, u drugom poglavlju daje se pregled literature i postojećih istraživanja na temu rada. U trećem poglavlju prikazuje se teorijski okvir metode konstantnih tržišnih udjela, kao i opis korištenih podataka i karakteristike uzorka istraživanja. U četvrtom poglavlju analiziraju se strukturna obilježja izvoza uslužnog sektora visoke dodane vrijednosti Republike Hrvatske na tržištu Europske unije. U posljednjem poglavlju rada sumiraju se svi relevantni rezultati i spoznaje iz istraživačkog dijela rada.

\section{Pregled literature}

Metoda konstantnih tržišnih udjela do sada je korištena za analizu tržišnog položaja niza zemalja u različitim vremenskim razdobljima, međutim sve provedene analize temeljile su se na robnoj razmjeni, dok je razmjena usluga s tog aspekta zanemarena. Tyczynski (1951) je prvi koristio ovu metodu u području vanjske trgovine, premda se ista primjenjivala i ranije u drugim ekonomskim područjima, poput analize zaposlenosti ili proizvodnosti rada.

Amador i Cabral (2008) su na primjeru Portugala dokazali kako je u razdoblju od 1968. do 2006. godine zabilježen blagi prosječni godišnji rast ukupnog tržišnog udjela u svijetu, uz različita kretanja u pojedinim podrazdobljima, uglavnom zbog učinka konkurentnosti. Athanasoglou i suradnici (2010) na primjeru Grčke, u vremenskom razdoblju od 1996. do 2006. godine, su dokazali kako je rast izvoza bio manji od potencijalnog, uglavnom zbog nepovoljne proizvodne specijalizacije i negativnog učinka konkurentnosti, dok je geografska struktura imala pozitivan učinak na rast izvoza. Sukladno istraživanju koje je provela Deutsche Bundesbank (2006) za razdoblje od 1985. do 2005. godine, smanjenje realnog tržišnog udjela Njemačke posljedica je nepovoljnog strukturnog učinka, naročito geografske specijalizacije, i negativnog učinka konkurentnosti, što se prije svega odnosi na prvih deset promatranih godina, dok nakon 1995. godine slijedi poboljšanje konkurentnosti i blagi oporavak udjela.

Istraživanje Europske središnje banke (2005) koje je obuhvatilo eurozonu i posebno zemlje članice, u vremenskom razdoblju od 1985. do 2001. godine, pokazalo je smanjenje tržišnog udjela eurozone na svjetskim tržištima, uglavnom zbog nepovoljne geografske specijalizacije (mali udio izvoza na azijska tržišta, odnosno orijentacija na europska tržišta koja u tom razdoblju rastu relativno sporo). Najveće zemlje, među kojima se ističu Francuska i Njemačka, najviše određuju ukupna 
izvozna ostvarenja eurozone. Finicelli i suradnici (2011) su dokazali kako je većina industrijaliziranih zemalja (od ukupno 62 promatrane zemlje), u razdoblju od 19985. do 2003. godine, izgubila tržišne udjele pod utjecajem snažnog rasta izvoza zemalja s tržištima u nastajanju, premda su u pravilu imale koristi od strukturnih učinaka, i to ili zbog specijalizacije u brzorastućim sektorima (visoko tehnološki intenzivne djelatnosti) ili brzorastućim tržištima (Azija). Foresti (2004) dokazuje snažnu izvoznu kontrakciju Italije u drugoj polovici 1990-ih godina, zbog pogoršanja konkurentnosti, koja se može objasniti aprecijacijom domaće valute i snažnom konkurencijom zemalja s niskim troškovima rada.

Michel (2005) je promatrao 21 europsku i neeuropsku zemlju i skupinu zemalja u vremenskom razdoblju od 1991. do 2001. godine te dokazao smanjenje svjetskih tržišnih udjela većine europskih zemalja, uglavnom zbog nepovoljnog učinka konkurentnosti. U neeuropskim zemljama tržišni udjeli su u razdoblju od 1991. do 1997. godine rasli, jer su pozitivni strukturni učinci nadjačali negativan učinak konkurentnosti, što se nije nastavilo i u narednom razdoblju. Skriner (2009) ističe da unatoč činjenici što je austrijski izvoz uspio održati svoj tržišni udio u globalnom okruženju u razdoblju od 1990. do 2006. godine, njegova se vrlo uska geografska i proizvodna specijalizacija ističe kao mogući izvor ranjivosti u budućnosti.

Ćudina, Lukinić Čardić i Sušić (2012) prvi puta analiziraju promjene relativnog položaja hrvatskog robnog izvoza, odnosno njegova udjela na tržištu Europske unije u razdoblju od 2000. do 2010. godine, primjenom metode konstantnih tržišnih udjela. Rezultati njihova rada pokazuju da je stagnacija udjela izvoza roba Republike Hrvatske na tržištu Europske unije u razdoblju od 2000. do 2010. godine poglavito posljedica nekonkurentnosti, dok je strukturni učinak (zbroj proizvodnog i geografskog učinka) blago pozitivan.

Buturac, Lovrinčević i Mikulić (2014) proveli su analizu kretanja izvoza tekstilne industrije Republike Hrvatske metodom konstantnih tržišnih udjela u razdoblju od 2002. do 2012. godine, kako bi kvantificirali pokazatelje vezane uz izvoznu konkurentnost hrvatske tekstilne industrije na globalnom i pojedinim inozemnim tržištima (EU15, EU27). Analizom su otkriveni relativno razočaravajući rezultati glede konkurentskog položaja hrvatske tekstilne industrije. Neuspjeh u tržišnom nadmetanju u izvozu osnovnih odjevnih proizvoda na tržištu EU15, EU27 i svjetskom tržištu razlog je loših izvoznih pokazatelja u cjelini.

Buturac, Lovrinčević i Mikulić (2017) u svojem su radu, korištenjem metode konstantnih tržišnih udjela i input-output analize, mjerili važnost prehrambenog sektora u Republici Hrvatskoj. Rezultati su pokazali da je gubitak konkurentnosti u prehrambenoj industriji u Republici Hrvatskoj bio najvažniji čimbenik koji je odredio pad udjela nacionalnih poduzeća, u razdoblju od 2009. godine, kada je započela svjetska gospodarska kriza, do 2013. godine, kada je Republika Hrvatska 
postala članicom Europske unije. Članstvo u Europskoj uniji značajno je i pozitivno utjecalo na izvoz hrvatske prehrambene industrije.

Madan i Sharma (2018) analizirali su tržišnu konkurentnost izvoza pšenice u Indiji, u razdoblju od 1991. do 2016. godine, korištenjem nominalnog koeficijenta zaštite i metode konstantnih tržišnih udjela. Analiza konstantnih tržišnih udjela pokazala je kako Indija ne ostvaruje konkurentske prednosti u izvozu pšenice u odnosu na ostatak svijeta, odnosno, proizvodni učinak i učinak konkurentnosti negativno su utjecali na izvoz pšenice iz Indije u promatranom razdoblju.

Gilbert i Muchová (2018) su korištenjem metode konstantnih tržišnih udjela analizirali promjene u udjelima izvoza roba i izvoznoj konkurentnosti u gospodarstvima zemalja srednje i istočne Europe, u razdoblju od petog proširenja Europske unije. Rezultati su pokazali da su tranzicijska gospodarstva zemalja srednje i istočne Europe općenito povećala svjetsku izvoznu konkurentnost. Promjene u izvoznoj konkurentnosti u regiji uglavnom su potaknute širenjem tržišnog udjela unutar Europske unije.

Budući da je prilikom pregleda literature, kako domaće, tako i inozemne, utvrđen nedostatak istraživanja o primjeni metode konstantnih tržišnih udjela na tržištu usluga, u ovome će se radu analizirati primjena navedene metode na izvoz uslužnog sektora visoke dodane vrijednosti Republike Hrvatske na tržište odabranih zemalja članica Europske unije, u vremenskom razdoblju od 2008. do 2012. godine.

\section{Metodološki okvir empirijskog istraživanja}

Relativan položaj neke zemlje na međunarodnom tržištu određuje, prije svega, njegova sposobnost da kvalitetom svojih proizvoda ili usluga nadjača konkurente (Ćudina i sur., 2012). Međutim, znatnu prednost u borbi za tržišnim udjelom može im omogućiti i povoljna proizvodna, odnosno uslužna i geografska struktura njihovog izvoza, odnosno intenzitet potražnje za njihovim proizvodima i uslugama na tržištima na kojima ih plasiraju, odnosno pružaju. U smislu potražnje važno je i u kojoj je mjeri šire regionalno okruženje neke zemlje dinamično. Vezano uz Republiku Hrvatsku, pitanje tržišnog položaja njenih izvoznika posebno je važno u kontekstu Europske unije, budući da je upravo Europska unija najvažnije izvozno tržište Republike Hrvatske.

Korisnost metode konstantnih tržišnih udjela proizlazi iz činjenice da pruža informacije na temelju kojih se može zaključiti da iako zemlja može imati nepromijenjen udio izvoza u određenim uslugama i na pojedinim tržištima, izvozni udio 
te zemlje na međunarodnim tržištima kumulativno se može smanjivati. Razlog tome može biti izvoz na tržište koje u prosjeku raste sporije od ukupnog svjetskog tržišta ili izvoz usluga za kojima potražnja raste sporije u odnosu na prosječni rast potražnje za drugim uslugama (Milana, 1988).

Dinamičko obilježje metode konstantnih tržišnih udjela pridonosi boljem razumijevanju strukturnih promjena i izvozne konkurentnosti tijekom vremena. Svaka zemlja će preferirati izvoziti one usluge i na ona tržišta koja se brzo razvijaju. Upravo rezultati metode konstantnih tržišnih udjela mogu ukazati na poželjnu izvoznu strukturu promatrane zemlje ili sektora.

\subsection{Teorijski okvir metode konstantnih tržišnih udjela}

Metoda konstantnih tržišnih udjela (engl. Constant Market Share, CMS) u ovome se radu po prvi puta primjenjuje u analizi izvoza uslužnog sektora visoke dodane vrijednosti Republike Hrvatske, pri čemu se razmatraju promjene udjela izvoza uslužnog sektora visoke dodane vrijednosti na tržištu zemalja članica Europske unije. Ćudina i suradnici (2012) navode kako je navedena metoda često primjenjiva u ekonometrijskim analizama vanjskotrgovinskih tokova te se njome promjena tržišnog udjela neke zemlje na određenom tržištu dovodi u vezu sa strukturnim i drugim karakteristikama njenog izvoza. Izvorna formulacija ove metode razdvaja promjenu tržišnog udjela na dva osnovna dijela koji zajedno daju ,ukupni učinak“. Prvi dio odnosi se na „strukturni učinak“ te je odraz same strukture izvoza i pokazuje koliko na izvozne rezultate može utjecati odabir usluge koja će se izvoziti, kao i odabir zemalja u koje cee se te usluge plasirati. Preostali dio predstavlja rezidualnu vrijednost, a naziva se „učinak konkurentnosti““. Opisi pojedinih učinaka metode konstantnih tržišnih udjela prikazani su u tablici 2. 


\section{Tablica 2.}

\section{OPISI UČINAKA METODE KONSTANTNIH TRŽIŠNIH UDJELA}

\begin{tabular}{|l|l|}
\hline \multicolumn{1}{|c|}{ Učinak } & \multicolumn{1}{c|}{ Opis značenja } \\
\hline Ukupni učinak (TE) & $\begin{array}{l}\text { Ukupni učinak mjeri promjenu izvoznog udjela pojedine uslužne dje- } \\
\text { latnosti sektora visoke dodane vrijednosti u ukupnom izvozu Europske } \\
\text { unije na godišnjoj razini. Pozitivna vrijednost ukazuje da izvoz proma- } \\
\text { trane uslužne djelatnosti raste brže u odnosu na rast izvoza te uslužne } \\
\text { djelatnosti koji ostvaruju zemlje članice Europske unije. Suprotno vrije- } \\
\text { di ako je vrijednost negativna. }\end{array}$ \\
\hline Uslužni učinak (UE) & $\begin{array}{l}\text { Dio rasta izvoza koji se pripisuje uslužnoj strukturi promatrane uslužne } \\
\text { djelatnosti sektora visoke dodane vrijednosti. Uslužni učinak je poziti- } \\
\text { van ako je izvoz koncentriran u uslugama za koje postoji relativno brzi } \\
\text { rast potražnje. Suprotno vrijedi u slučaju negativne vrijednosti uslužnog } \\
\text { učinka. }\end{array}$ \\
\hline Geografski učinak (GE) & $\begin{array}{l}\text { Geografski učinak mjeri efekt na rast izvoza koji proizlazi iz geograf- } \\
\text { ske strukture izvoza. Ovaj učinak je pozitivan ako je izvoz promatrane } \\
\text { uslužne djelatnosti sektora visoke dodane vrijednosti koncentriran na } \\
\text { brzo rastuća izvozna odredišta. Negativna vrijednost pokazuje da je } \\
\text { izvoz koncentriran na odredišta gdje je rast potražnje sporiji u odnosu } \\
\text { na zemlje članice Europske unije. }\end{array}$ \\
\hline $\begin{array}{l}\text { Miješani strukturni } \\
\text { učinak (MIX) }\end{array}$ & $\begin{array}{l}\text { Učinak konkurentnosti ukazuje na sposobnost promatrane uslužne } \\
\text { djelatnosti sektora visoke dodane vrijednosti da poveća tržišni udio is- } \\
\text { ključivo zbog rasta konkurentnosti, neovisno o uslužnoj ili geografskoj } \\
\text { strukturi izvoza. Pozitivna vrijednost upućuje na konkurentske predno- } \\
\text { sti promatrane uslužne djelatnosti sektora visoke dodane vrijednosti u } \\
\text { odnosu na zemlje članice Europske unije, dok negativna vrijednost na } \\
\text { gubitak konkurentskih prednosti. }\end{array}$ \\
$\begin{array}{l}\text { Miješani strukturni učinak mjeri razliku između ukupnog učinka i } \\
\text { sume uslužnog učinka, geografskog učinka i učinka konkurentnosti. } \\
\text { Navedeni učinak nema ekonomsko značenje, već samo statističku svrhu. }\end{array}$ \\
\hline Bunkurentnosting
\end{tabular}

Izvor: Prilagođeno prema Buturac, G., Lovrinčević, Ž. i Mikulić, D. (2014.). Export Competitiveness of Croatian Textile Industry - CMS Analysis and Importance for Economy, Textil ve Konfeksiyon, 24 (2), str. 158-168.

Izvornoj formulaciji pripisivali su se brojni nedostaci, poglavito vezani uz konstrukciju modela i interpretaciju pojedinih učinaka ${ }^{1}$. Protekom vremena me-

${ }^{1}$ Na primjer, Simonis (2000) je u radu istaknuo kako se pri konstrukciji modela javlja problem indeksnog broja, jer primjena različitih skupnih agregatnih indeksa utječe na veličinu i 
toda konstantnih tržišnih udjela je evoluirala, a njene najvažnije preinake u odnosu na izvornu formulaciju objavljene su u radovima Richardson (1971a i 1971b) i Milana (1988). U ovom se radu koristi formulacija metode konstantnih tržišnih udjela koju je 2005. godine razvila Europska središnja banka (engl. European Central Bank, u nastavku ECB), a koja je na zadovoljavajući način otklonila većinu uočenih nedostataka. Prema ECB-ovoj formulaciji metode konstantnih tržišnih udjela, primijenjenoj na Republici Hrvatskoj, ukupni učinak (engl. total effect, u nastavku TE) predstavlja postotnu promjenu tržišnog udjela hrvatskog izvoza na tržištu Europske unije, a jednak je zbroju strukturnog učinka (engl. structure effect, SE) i učinka konkurentnosti (engl. competitiveness effect, CE). ECB (2005) navodi i određene nedostatke koje metoda sadrži. Kao deskriptivna metoda, ne ispituje uzročno-posljedične veze između tržišnog udjela i ostalih ekonomskih varijabli, poput realnog efektivnog tečaja. Usprkos tome, metoda konstantnih tržišnih udjela pruža koristan uvid u strukturne karakteristike izvoza i njegov utjecaj na izvozne rezultate, zbog čega je često polazišna točka ekonometrijskih modela u sklopu kojih se ispituju odrednice tržišnog položaja neke zemlje ili integracije. Osim toga, problem ove metode mogu predstavljati i odabrane frekvencije podataka, premda se izborom godišnjih podataka, što je pristup korišten u ovome radu, uvelike umanjio problem promjene strukture izvoza između dva analizirana razdoblja (problem indeksnog broja).

Kako bi se analizirala promjena relativnog položaja izvoza uslužnog sektora visoke dodane vrijednosti Republike Hrvatske na tržište Europske unije te utvrdili uzroci promjena udjela izvoza usluga Republike Hrvatske na tržištu Europske unije u razdoblju od 2008. do 2012. godine, ukupni učinak ${ }^{2}$ razdjeljuje se na strukturni učinak i učinak konkurentnosti prema sljedećoj formuli:

$$
T E=g+g^{*}=[\underbrace{\left.\sum_{i} \sum_{j}\left(\theta_{i j}-\theta_{i j}^{*}\right) g_{i j}^{*}\right]}_{\text {UKUPNI UČINAK }}+\underbrace{\left[\sum_{i} \sum_{j} \theta_{i j}\left(g_{i j}-g_{i j}^{*}\right)\right]}_{\text {STRUKTURNI UČINAK }}
$$
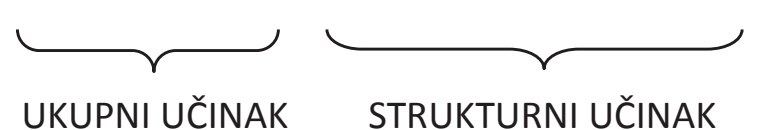

predznak izračunatih učinaka. Uz navedeno, kao znatna slabost izvorne formulacije može se istaknuti i činjenica da „učinak konkurentnosti“, budući da je izračunat kao rezidualna vrijednost, obuhvaća i međudjelovanje dvaju osnovnih učinaka, čime je otežana njegova interpretacija (Ćudina i sur., 2012).

${ }^{2}$ Kako je ranije u radu objašnjeno, prema definiciji ECB-a, ukupni učinak (TE) jednak je zbroju strukturnog učinka $(g)$ i učinka konkurentnosti $\left(g^{*}\right), t j$. TE $=g+g^{*}$. Međutim, u radu ECB-a (2005, Anex II, str. 85.) pogrešno stoji formula, prema kojoj je ukupni učinak jednak razlici strukturnog učinka i učinka konkurentnosti, tj. TE $=\mathrm{g}-\mathrm{g}^{*}$. 
pri čemu je

$g$ - stopa rasta ukupnog izvoza uslužnog sektora visoke dodane vrijednosti Republike Hrvatske u zemlje članice Europske unije između dva razdoblja, a računa se prema formuli $g=\sum_{i} \sum_{j} \theta_{i j} g_{i j}$,

$g^{*}$ - stopa rasta ukupnog uvoza uslužnog sektora visoke dodane vrijednosti zemalja članica Europske unije između dva razdoblja, a računa se prema formuli $g^{*}=\sum_{i} \sum_{j} \theta_{i j}^{*} g_{i j}^{*}$

$g_{i j}$ - stopa rasta izvoza uslužne djelatnosti $i$ sektora visoke dodane vrijednosti Republike Hrvatske u EU članicu $j$ u razdoblju $t$,

$g_{i j}^{*}$ - stopa rasta uvoza uslužne djelatnosti $i$ sektora visoke dodane vrijednosti u EU članicu $j$ u razdoblju $t$,

$\theta_{i j}$ - udio uslužne djelatnosti $i$ sektora visoke dodane vrijednosti u izvozu uslužnog sektora visoke dodane vrijednosti Republike Hrvatske u EU članicu $j \mathrm{u}$ razdoblju $t-1$,

$\theta_{i j}^{*}$ - udio uslužne djelatnosti $i$ sektora visoke dodane vrijednosti u uvozu uslužnog sektora visoke dodane vrijednosti EU članice $j$ u razdoblju $t-1$.

Prema metodi konstantnih tržišnih udjela ukupni učinak predstavlja postotnu promjenu tržišnog udjela izvoza uslužnog sektora visoke dodane vrijednosti Republike Hrvatske na tržište Europske unije. Strukturni učinak dalje se raščlanjuje na proizvodni učinak, geografski učinak (u nastavku GE) i miješani strukturni učinak (engl. mixed structure effect, MIX). Budući da se u ovom radu ne analizira robna trgovina i izvoz roba, već izvoz uslužnog sektora visoke dodane vrijednosti, tzv. proizvodni učinak preimenovan je u uslužni učinak (u nastavku UE) i identičan je proizvodnom učinku. Svi navedeni učinci se izračunavaju na sljedeći način:

$$
S E=\underbrace{\sum_{i}\left(\theta_{i}-\theta_{i}^{*}\right) g_{i}^{*}}_{\text {USLUŽNI UČINAK }}+\underbrace{\sum_{j}\left(\theta_{j}-\theta_{j}^{*}\right) g_{j}^{*}}_{\text {GEOGRAFSKI UČINAK }}+\underbrace{\sum_{i} \sum_{j}\left[\left(\theta_{i j}-\theta_{i j}^{*}\right)-\left(\theta_{i}-\theta_{i}^{*}\right) \frac{\theta_{i j}^{*}}{\theta_{i}^{*}}-\left(\theta_{j}-\theta_{j}^{*}\right) \frac{\theta_{i j}^{*}}{\theta_{j}^{*}}\right] g_{i j}^{*}}_{\text {MIJEŠANI STRUKTURNI UČINAK }}
$$
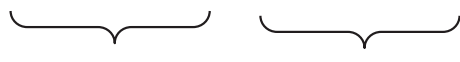

${ }^{3}$ ECB (2005) u svom radu uspoređuje rast izvoza roba euro područja i rast svjetskog izvoza roba, dok se u ovom radu uspoređuje rast izvoza usluga visoke dodane vrijednosti Republike Hrvatske i uvozna potražnja uslužnog sektora visoke dodane vrijednosti iz zemalja članica Europske unije, zbog čega postoje odstupanja u odnosu na ECB (2005) u definiranju varijabli: $g^{*}, g_{i j}, \theta_{i j}{ }^{*}$. Prema Milana (1988), oba su pristupa prihvatljiva. 
pri čemu je ${ }^{4}$ :

$g_{i}^{*}$ - rast uvoza uslužne djelatnosti $i$ sektora visoke dodane vrijednosti u zemljama članicama EU u razdoblju $t$,

$g_{j}^{*}-$ rast ukupnog uvoza uslužnog sektora visoke dodane vrijednosti u zemlju članicu EU $j$ u razdoblju $t$,

$\theta_{i}$ - udio uslužne djelatnosti $i$ sektora visoke dodane vrijednosti u izvozu uslužnog sektora visoke dodane vrijednosti Republike Hrvatske u zemlje članice EU u razdoblju $t$ - 1 ,

$\theta_{i}^{*}-$ udio uslužne djelatnosti $i$ sektora visoke dodane vrijednosti u ukupnom uvozu uslužnog sektora visoke dodane vrijednosti zemalja članica EU u razdoblju $t-1$,

$\theta_{j}$ - udio zemlje članice EU $j$ u izvozu uslužnog sektora visoke dodane vrijednosti Republike Hrvatske u razdoblju $t$ - 1 ,

$\theta_{j}^{*}$ - udio zemlje članice EU $j$ u ukupnom uvozu uslužnog sektora visoke dodane vrijednosti svih zemalja članica EU u razdoblju $t-1$.

Prema navedenoj formuli, uslužni učinak za Republiku Hrvatsku je pozitivan i doprinosi rastu tržišnog udjela u onim uslužnim djelatnostima sektora visoke dodane vrijednosti koja su u domaćem izvozu zastupljenija nego u izvozu zemalja članica Europske unije (, a tim je veći što je uvozna potražnja za tim uslugama na tržištu zemalja članica Europske unije ( veća. Na primjer, ukoliko Republika Hrvatska u zemlje članice Europske unije izvozi više stručnih, znanstvenih i tehničkih usluga nego li druge zemlje, a potražnja za tim uslugama je velika, tada ona u toj uslužnoj djelatnosti bilježi pozitivan uslužni učinak i posljedično povećava tržišni udio samo zato što je u relativnoj prednosti pred zemljama članicama Europske unije. Također, Republika Hrvatska generira pozitivne geografske učinke na tržištima onih zemalja članica Europske unije koja su domaćim izvoznicima relativno važnija nego drugim izvoznicima ( i veći je što je uvozna potražnja tih zemalja članica veća. Budući da geografska i uslužna struktura izvoza nisu međusobne neovisne, njihov je zajednički utjecaj, prema metodi konstantnih tržišnih udjela, sadržan u miješanom strukturnom učinku ${ }^{5}$. Preostalom učinku konkurentnosti pripisuje se svaka promjena tržišnog udjela koja ne proizlazi iz uslužnog,

${ }^{4}$ ECB (2005) u svom radu uspoređuje rast izvoza roba euro područja i rast svjetskog izvoza roba, dok se u ovom radu uspoređuje rast izvoza usluga visoke dodane vrijednosti Republike Hrvatske i uvozna potražnja uslužnog sektora visoke dodane vrijednosti iz zemalja članica Europske unije, zbog čega postoje odstupanja u odnosu na ECB (2005) u definiranju varijabli: $g_{i}{ }^{*}, g_{j}{ }^{*}, \theta_{i}^{*}, \theta_{j}^{*}$. Prema Milana (1988), oba su pristupa prihvatljiva.

${ }^{5} \mathrm{~S}$ obzirom na njegovu (statističku) svrhu, u radu mu se neće pridavati zasebno ekonomsko značenje, niti ga se posebno tumačiti. Takav pristup slijedi većina autora koji se koriste dorađenom verzijom metode konstantnih tržišnih udjela. 
geografskog i miješanog strukturnog učinka. Učinak konkurentnosti prema tome može obuhvaćati razne čimbenike koji potiču konkurentnost izvoznika, kao što su tehnološke inovacije, kvaliteta usluga, devizni tečaj i slično.

\subsection{Opis korištenih podataka i karakteristike uzorka istraživanja}

Za procjenu promjena relativnog položaja izvoza uslužnog sektora visoke dodane vrijednosti Republike Hrvatske na tržište Europske unije te utvrđivanje uzroka promjena tržišnog udjela izvoza uslužnog sektora visoke dodane vrijednosti u razdoblju od 2008. do 2012. godine koriste se podaci Državnog zavoda za statistiku (Strukturne poslovne statistike te kupljeni podaci o razini izvoza i uvoza uslužnog sektora visoke dodane vrijednosti) i Eurostata (Trade by NACE Rev. 2 activity and enterprise size class). Za utvrđivanje kretanja uslužnog sektora visoke dodane vrijednosti Republike Hrvatske i zemalja članica Europske unije, s aspekta udjela sektora u realnoj bruto dodanoj vrijednosti koriste se podaci Državnog zavoda za statistiku i Eurostata, za vremensko razdoblje od 2006. do 2012. godine, dok se za analizu s aspekta strukturnih obilježja koriste podaci za vremensko razdoblje od 2008. do 2012. godine, budući da ne postoje raspoloživi podaci za ranije razdoblje na ovom uzorku zemalja i djelatnostima koje čine uslužni sektor visoke dodane vrijednosti. Također, kako se računaju stope rasta izvoza uslužnog sektora visoke dodane vrijednosti, a ne postoje podaci za zemlje članice Europske unije u 2007. godini, interpretacija rezultata odnosi se na razdoblje od 2009. do 2012. godine.

Sukladno podacima Državnog zavoda za statistiku o volumenu međunarodne trgovine uslugama informacija i komunikacija, stručnih, znanstvenih i tehničkih djelatnosti te administrativnih i pomoćnih uslužnih djelatnosti, u vremenskom razdoblju od 2004. do 2012. godine, 90\% izvoza uslužnog sektora visoke dodane vrijednosti Republike Hrvatske odlazi u deset zemalja članica Europske unije, stoga će se promjene tržišnog udjela uslužnog sektora visoke dodane vrijednosti Republike Hrvatske analizirati na tržištima tih zemalja. To su sljedeće zemlje članice Europske unije: Slovenija, Njemačka, Italija, Austrija, Nizozemska, Ujedinjeno Kraljevstvo, Češka, Mađarska, Slovačka i Švedska. Od navedenih deset, šest zemalja je geografski smješteno blizu Republike Hrvatske te, u skladu s time, veći volumen trgovine uslugama visoke dodane vrijednosti s navedenim zemljama može biti zbog geografske blizine. 


\section{Rezultati empirijske analize}

Sukladno podacima prikazanima u tablici 3., izvoz djelatnosti uslužnog sektora visoke dodane vrijednosti Republike Hrvatske na tržište Europske unije u 2012. godini sudjelovao je s udjelom od 7,71\% u ukupnom izvozu cijelog uslužnog sektora.

\section{Tablica 3 .}

\section{IZVOZ I UDIO U UKUPNOM IZVOZU DJELATNOSTI USLUŽNOG SEKTORA ${ }^{6}$ REPUBLIKE HRVATSKE NA TRŽIŠTE EUROPSKE UNIJE, U 2012. GODINI, U TISUĆAMA EURA I POSTOCIMA}

\begin{tabular}{|l|r|r|}
\hline \multicolumn{1}{|c|}{ Djelatnosti uslužnog sektora } & Izvoz (tis. $€$ ) & $\begin{array}{c}\text { Udio u ukupnom } \\
\text { izvozu uslužnog } \\
\text { sektora (\%) }\end{array}$ \\
\hline F Građevinarstvo & $35.553,98$ & 5,15 \\
\hline $\begin{array}{l}\text { G Trgovina na veliko i malo; popravak motornih vozila i } \\
\text { motocikala }\end{array}$ & $540.425,94$ & 78,41 \\
\hline H Prijevoz i skladištenje & $35.732,18$ & 5,18 \\
\hline J Informacije i komunikacije & $18.436,64$ & 2,67 \\
\hline K Financijske djelatnosti i djelatnosti osiguranja & $6.703,48$ & 0,97 \\
\hline L Poslovanje nekretninama & $17.664,33$ & 2,56 \\
\hline M Stručne, znanstvene i tehničke djelatnosti & $26.481,7$ & 3,84 \\
\hline N Administrativne i pomoćne uslužne djelatnosti & $8.231,9$ & 1,19 \\
\hline UKUPNO & $689.230,15$ & 100 \\
\hline
\end{tabular}

Izvor: izrada autora prema Eurostat (2018) Trade by NACE Rev. 2 activity and enterprise size class [online]. Dostupno na: http://appsso.eurostat.ec.europa.eu/nui/show.do?dataset=ext_tec01\&lang=en (pristupljeno 26.08.2018.).

Međutim, kako bi se zornije prikazao strukturni pomak koji se dogodio od tradicionalnih djelatnosti, čiji udjeli u realnoj bruto dodanoj vrijednosti dugoročno padaju (poljoprivreda, šumarstvo i ribarstvo - djelatnost A, prerađivačka industrija - djelatnost C, građevinarstvo - djelatnost F, trgovina na veliko i na malo - dje-

6 Uslužni sektor obuhvaća djelatnosti od oznake $F$ do oznake $S$, sukladno NKD 2007. klasifikaciji ekonomskih djelatnosti. Međutim, za 2012. godinu raspoloživi su podaci samo za djelatnosti navedene u tablici 3. 
latnost $\mathrm{G}$, prijevoz i skladištenje - djelatnost $\mathrm{H}$ ), prema djelatnostima čiji udjeli u realnoj bruto dodanoj vrijednosti rastu (djelatnosti uslužnog sektora visoke dodane vrijednosti - J, M i N), na slici 1. prikazani su udjeli tradicionalnih djelatnosti i djelatnosti uslužnog sektora visoke dodane vrijednosti u realnoj bruto dodanoj vrijednosti za Republiku Hrvatsku, u razdoblju od 2004. do 2012. godine.

\section{Slika 1 .}

\section{UDJELI TRADICIONALNIH DJELATNOSTI I DJELATNOSTI USLUŽNOG SEKTORA VISOKE DODANE VRIJEDNOSTI U BRUTO DODANOJ VRIJEDNOSTI U REPUBLICI HRVATSKOJ, U RAZDOBLJU OD 2004. DO 2012. GODINE, U POSTOCIMA}

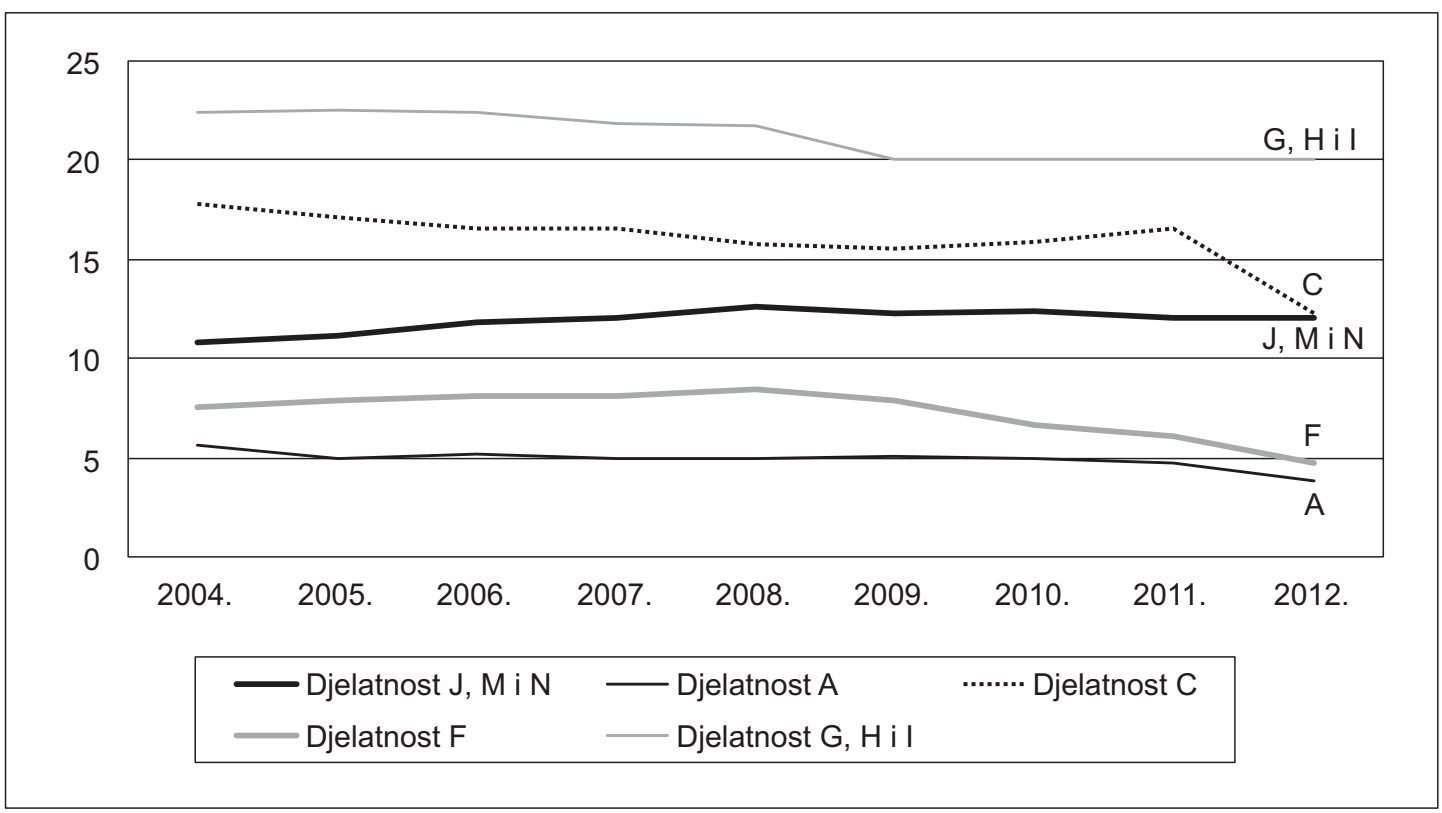

A - Poljoprivreda, šumarstvo i ribarstvo, C - Prerađivačka industrija, F - Građevinarstvo, G Trgovina na veliko i na malo, $\mathrm{H}$ - Prijevoz i skladištenje, J - Informacije i komunikacije, M Stručne, znanstvene i tehničke djelatnosti, N-Administrativne i pomoćne uslužne djelatnosti.

Izvor: obrada autora prema DZS (2013.). Strukturne poslovne statistike, Zagreb: Državni zavod za statistiku.

Radi lakše interpretacije rezultata metode konstantnih tržišnih udjela, koji se daju u nastavku rada, a naročito dijela koji se odnosi na strukturni učinak, potrebno je poznavati strukturu izvoza uslužnog sektora visoke dodane vrijednosti Republike Hrvatske prema uslužnoj i geografskoj orijentaciji te je usporediti s uvo- 
znom potražnjom uslužnog sektora visoke dodane vrijednosti iz zemalja članica Europske unije. Promatrajući uslužnu strukturu (tablica 4.), u hrvatskom izvozu uslužnog sektora visoke dodane vrijednosti na tržište Europske unije prevladava uslužna djelatnost informacija i komunikacija (43,64\% udjela izvoza djelatnosti J u ukupnom izvozu usluga visoke dodane vrijednosti Republike Hrvatske na tržište Europske unije). Nakon njih, s udjelom izvoza od 42,10\% slijede stručne, znanstvene i tehničke djelatnosti, dok su administrativne i pomoćne uslužne djelatnosti, s udjelom izvoza od 14,26\% u ukupnom izvozu usluga visoke dodane vrijednosti Republike Hrvatske na tržište Europske unije, na začelju.

Tablica 4 .

USPOREDBA STRUKTURE I DINAMIKE HRVATSKOG IZVOZA USLUŽNOG SEKTORA VISOKE DODANE VRIJEDNOSTI NA TRŽIŠTE EUROPSKE UNIJE I UKUPNE UVOZNE POTRAŽNJE IZ ZEMALJA ČLANICA EUROPSKE UNIJE, PREMA DJELATNOSTIMA KOJE GA ČINE, U RAZDOBLJU OD 2004. DO 2012. GODINE, U POSTOCIMA

\begin{tabular}{|l|c|c|c|c|}
\hline \multirow{2}{*}{$\begin{array}{c}\text { Djelatnost uslužnog sektora visoke } \\
\text { dodane vrijednosti }\end{array}$} & \multicolumn{2}{|c|}{$\begin{array}{c}\text { Izvoz usluga visoke } \\
\text { dodane vrijednosti iz RH } \\
\text { u zemlje članice EU }\end{array}$} & $\begin{array}{c}\text { Ukupni uvoz usluga } \\
\text { visoke dodane vrijednosti } \\
\text { zemalja članica EU* }\end{array}$ \\
\cline { 2 - 5 } & udio (\%) & $\begin{array}{c}\text { prosječna } \\
\text { godišnja stopa } \\
\text { promjene (\%) }\end{array}$ & udio (\%) & $\begin{array}{c}\text { prosječna } \\
\text { godišnja stopa } \\
\text { promjene (\%) }\end{array}$ \\
\hline J Informacije i komunikacije & 43,64 & $-1,30$ & 15,19 & 4,77 \\
\hline $\begin{array}{l}\text { M Stručne, znanstvene i tehničke } \\
\text { djelatnosti }\end{array}$ & 42,10 & 8,25 & 49,48 & $-18,52$ \\
\hline $\begin{array}{l}\text { N Administrativne i pomoćne uslužne } \\
\text { djelatnosti }\end{array}$ & 14,26 & 17,04 & 35,33 & $-28,20$ \\
\hline UKUPNO & 100,00 & 4,67 & 100,00 & $-17,85$ \\
\hline
\end{tabular}

Izvor: izračun autora prema Eurostat (2016b.). Trade by NACE Rev. 2 activity and enterprise size class [online]. Dostupno na http://appsso.eurostat.ec.europa.eu/nui/submitViewTableAction.do (pristupljeno 29.09.2016.) i kupljenim podacima Državnog zavoda za statistiku.

*Napomena: Zbog neraspoloživosti podataka, podaci za uvoz usluga visoke dodane vrijednosti zemalja članica Europske unije odnose se na vremensko razdoblje od 2008. do 2012. godine.

Iz tablice 4. vidljivo je da kod stručnih, znanstvenih i tehničkih djelatnosti (djelatnost M), koje čine visoki udio u hrvatskom izvozu usluga visoke dodane vrijednosti, uvozna potražnja s tržišta zemalja članica Europske unije u razdoblju od 2008. do 2012. godine za tim uslužnim djelatnostima pada u prosjeku za -18,52\% 
godišnje. S druge strane, kod djelatnosti informacija i komunikacija (djelatnost J), za kojima uvozna potražnja s tržišta zemalja članica Europske unije raste prosječnom godišnjom stopom od 4,77\%, prosječna godišnja stopa hrvatskog izvoza na tržište Europske unije pada za $-1,30 \%$. Konačno, kod administrativnih i pomoćnih uslužnih djelatnosti (djelatnost $\mathrm{N}$ ) uvozna potražnja s tržišta zemalja članica Europske unije pada godišnje u prosjeku za $-28,20 \%$, dok prosječna godišnja stopa hrvatskog izvoza na tržište Europske unije raste za 17,04\%.

U geografskoj strukturi hrvatskog izvoza uslužnog sektora visoke dodane vrijednosti u zemlje članice Europske unije (tablica 5.) prevladava pet zemalja članica Europske unije u koje odlazi preko tri četvrtine domaćeg izvoza uslužnog sektora visoke dodane vrijednosti: Slovenija (s udjelom od 28,12\%), Njemačka $(15,05 \%)$, Italija (14,57\%), Austrija (10,80\%) i Nizozemska (7,06\%). Međutim, prema relativnom značaju, od navedenih je tržišta jedino nizozemsko tržište drugim izvoznicima jednako važno kao i Republici Hrvatskoj (na nizozemsko tržište općenito u prosjeku godišnje odlazi 3,20\% svih usluga visoke dodane vrijednosti plasiranih u Europsku uniju, što je najsličnije udjelu te zemlje u hrvatskom izvozu usluga visoke dodane vrijednosti u Europsku uniju). Slovenija, Italija i Austrija, koje su Republici Hrvatskoj važni vanjskotrgovinski partneri, izvoznicima iz drugih zemalja u prosjeku su manje važne. Njima je od posebne važnosti Njemačka, u koju, u razdoblju od 2008. do 2012. godine, prosječno godišnje odlazi 38,83\% svih usluga visoke dodane vrijednosti plasiranih u Europsku uniju. Nakon Njemačke, Ujedinjeno Kraljevstvo druga je od promatranih zemalja u koju odlazi najviše usluga visoke dodane vrijednosti plasiranih u Europsku uniju (prosječno godišnje 8,79\%). U ostale stare zemlje članice EU15 godišnje u prosjeku odlazi 38,69\% svih plasiranih usluga visoke dodane vrijednosti u Europskoj uniji, dok, u prosjeku, svega 2,51\% odlazi u ostale nove zemlje članice EU12. S druge strane, udjeli izvoza usluga visoke dodane vrijednosti iz Republike Hrvatske približno su jednaki i u ostalim starim zemljama članicama EU15 (5,57\%), kao i u ostalim novim zemljama članicama EU12 (5,51\%). 
Z. LACKOVIĆ VINCEK, V. BILAS, M. BOŠNJAK: Primjena metode konstantnih tržišnih udjela na izvoz uslužnog sektora... EKONOMSKI PREGLED, 70 (3) 351-379 (2019)

\section{Tablica 5.}

STRUKTURA I DINAMIKA HRVATSKOG IZVOZA USLUŽNOG SEKTORA VISOKE DODANE VRIJEDNOSTI NA TRŽIŠTE EUROPSKE UNIJE I UKUPNE UVOZNE POTRAŽNJE IZ ZEMALJA ČLANICA EUROPSKE UNIJE, PREMA ZEMLJAMA, U RAZDOBLJU OD 2004. DO 2012. GODINE, U POSTOCIMA

\begin{tabular}{|l|c|c|c|c|}
\hline \multirow{2}{*}{ Zemlja odredišta } & \multicolumn{2}{|c|}{$\begin{array}{c}\text { Izvoz usluga visoke dodane } \\
\text { vrijednosti iz RH u zemlje } \\
\text { članice EU }\end{array}$} & \multicolumn{2}{c|}{$\begin{array}{c}\text { Ukupni uvoz usluga visoke } \\
\text { dodane vrijednosti zemalja } \\
\text { članica EU* }\end{array}$} \\
\cline { 2 - 5 } & udio (\%) & $\begin{array}{c}\text { prosječna } \\
\text { godišnja stopa } \\
\text { promjene (\%) }\end{array}$ & udio (\%) & $\begin{array}{c}\text { prosječna } \\
\text { godišnja stopa } \\
\text { promjene (\%) }\end{array}$ \\
\hline Slovenija & 28,12 & 1,47 & 0,23 & $-5,61$ \\
\hline Njemačka & 15,05 & 3,37 & 38,83 & $-30,59$ \\
\hline Italija & 14,47 & 3,25 & 2,42 & 4,38 \\
\hline Austrija & 10,80 & $-3,99$ & 1,92 & 5,84 \\
\hline Nizozemska & 7,06 & 39,28 & 3,20 & 19,17 \\
\hline Ujedinjeno Kraljevstvo & 4,62 & 28,46 & 8,79 & $-6,28$ \\
\hline Češka & 2,50 & 11,52 & 0,71 & $-2,17$ \\
\hline Mađarska & 2,48 & $-1,70$ & 0,41 & 0,04 \\
\hline Slovačka & 1,95 & 17,83 & 1,10 & 15,77 \\
\hline Švedska & 1,87 & $-25,51$ & 1,19 & 41,57 \\
\hline $\begin{array}{l}\text { Ostale stare zemlje članice } \\
\text { EU15 }\end{array}$ & 5,57 & 4,35 & 38,69 & $-24,46$ \\
\hline $\begin{array}{l}\text { Ostale nove zemlje članice } \\
\text { EU12 }\end{array}$ & 5,51 & 15,25 & 2,51 & $-2,99$ \\
\hline UKUPNO & 100,0 & 4,67 & 100,0 & $-17,28$ \\
\hline
\end{tabular}

Izvor: izračun autora prema Eurostat (2016b.). Trade by NACE Rev. 2 activity and enterprise size class [online]. Dostupno na http://appsso.eurostat.ec.europa.eu/nui/submitViewTableAction.do (pristupljeno 29.09.2016.) i kupljenim podacima Državnog zavoda za statistiku.

*Napomena: Zbog neraspoloživosti podataka, podaci za uvoz usluga visoke dodane vrijednosti zemalja članica Europske unije odnose se na vremensko razdoblje od 2008. do 2012. godine.

U razdoblju od 2008. do 2011. godine potražnja za uslugama visoke dodane vrijednosti s tržišta Europske unije rasla je prosječnom godišnjom stopom od 6,14\%, no zbog pada prosječne godišnje stope potražnje u 2012. godini od 
$-60,85 \%$, ostvaren je pad prosječne godišnje stope potražnje u razdoblju od 2008. do 2012. godine za -17,28\%. Kada se promatra dinamika uvozne potražnje s tržišta zemalja članica Europske unije (tablica 5.), u razdoblju od 2008. do 2012. godine, može se primijetiti kako je na pad potražnje za uslugama visoke dodane vrijednosti na tržištu Europske unije prvenstveno utjecao pad potražnje s njemačkog tržišta $(-30,59 \%)$. U Ujedinjenom Kraljevstvu ostvaren je pad prosječne godišnje stope potražnje za $-6,28 \%$, u Sloveniji za $-5,61 \%$, a u Češkoj za $-2,17 \%$. S druge strane, potražnja sa švedskog tržišta rasla je po stopi od 41,57\%, s nizozemskog tržišta po stopi od 19,17\% te sa slovačkog tržišta po stopi od 15,77\%. Rast potražnje za uslugama visoke dodane vrijednosti iz Republike Hrvatske u razdoblju od 2004. do 2012. godine bio je najveći s tržišta Nizozemske (39,28\%), Ujedinjenog Kraljevstva $(28,46 \%)$ i Slovačke $(17,83 \%)$.

Iz specifičnosti uslužne strukture hrvatskog izvoza uslužnog sektora visoke dodane vrijednosti i dinamike uvozne potražnje na tržištu Europske unije, proizlazi uslužni učinak (UE), prikazan u tablici 6. Analizirajući ukupne iznose uslužnog učinka izvoza uslužnog sektora visoke dodane vrijednosti Republike Hrvatske na tržištu Europske unije u razdoblju od 2009. do 2012. godine, prikazane u tablici 6., vidljiv je negativan uslužni učinak promjene tržišnog udjela kod stručnih, znanstvenih i tehničkih djelatnosti (djelatnosti $\mathrm{M}$ ), što znači da u promatranom razdoblju za djelatnošću $M$ nije ostvarena rastuća potražnja s tržišta Europske unije $(-0,011 \%)$. Navedeno potvrđuje i tablica 4., koja pokazuje vrlo visoki udio izvoza stručnih, znanstvenih i tehničkih djelatnosti Republike Hrvatske na tržište Europske unije $(42,10 \%)$, za kojima uvozna potražnja s tržišta zemalja članica Europske unije pada u prosjeku za -18,52\% godišnje. S druge strane, zbog visokog udjela u izvozu uslužnog sektora visoke dodane vrijednosti, Republika Hrvatska u djelatnosti informacija i komunikacija (djelatnost $\mathrm{J}$ ) bilježi pozitivan uslužni učinak $(0,006 \%)$, za kojom, sukladno podacima iz tablice 3 , potražnja s tržišta Europske unije raste prosječno godišnje za $4,77 \%$. 
Tablica 6.

USLUŽNI UČINAK IZVOZA USLUŽNOG SEKTORA VISOKE DODANE VRIJEDNOSTI REPUBLIKE HRVATSKE NA TRŽIŠTE EUROPSKE UNIJE, PREMA DJELATNOSTIMA, U RAZDOBLJU OD 2009.7 DO 2012. GODINE, U POSTOCIMA

\begin{tabular}{|c|c|c|c|}
\hline Godina & Djelatnost J & Djelatnost M & Djelatnost $\mathbf{~}$ \\
\hline 2009. & $-0,016$ & $-0,004$ & 0,027 \\
\hline 2010. & 0,063 & 0,002 & $-0,028$ \\
\hline 2011. & $-0,025$ & $-0,013$ & $-0,007$ \\
\hline 2012. & 0,001 & $-0,028$ & 0,050 \\
\hline Ukupni uslužni učinak & $\mathbf{0 , 0 0 6}$ & $\mathbf{- 0 , 0 1 1}$ & $\mathbf{0 , 0 1 1}$ \\
\hline
\end{tabular}

$\mathrm{J}$ - Informacije i komunikacije, M - Stručne, znanstvene i tehničke djelatnosti, N - Administrativne i pomoćne uslužne djelatnosti.

Izvor: izračun autora.

Geografski učinak (GE) mjeri efekt na izvozni rast koji proizlazi iz geografske strukture izvoza. Temeljem podataka prikazanim u tablici 7., vidljiv je negativan geografski učinak izvoza uslužnog sektora visoke dodane vrijednosti 2009. godine $(-0,094 \%)$ i 2012 . godine $(-0,057 \%)$, što potvrđuje nepovoljnu geografsku strukturu izvoza uslužnog sektora visoke dodane vrijednosti Republike Hrvatske, i to prije svega zbog velike izvozne koncentracije na slovensko i njemačko tržište, gdje potražnja raste sporije u odnosu na ostatak europskog tržišta. Navedeno potvrđuju i podaci prikazani u tablici 5., gdje je vidljivo kako je prosječni godišnji pad potražnje s njemačkog tržišta u razdoblju od 2008. do 2012. godine iznosio $-30,59 \%$, a sa slovenskog tržišta $-5,61 \%$. S druge strane, pozitivan geografski učinak izvoza uslužnog sektora visoke dodane vrijednosti Republike Hrvatske vidljiv je 2010. godine $(0,002 \%)$ i 2011. godine $(0,026 \%)$, što znači da je izvoz promatranog sektora bio koncentriran na brzo rastuća izvozna odredišta, prije svega na austrijsko i talijansko tržište, na kojima je, sukladno podacima iz tablice 5., zabilježen prosječni godišnji porast potražnje, i to za 5,84\% na austrijskom tržištu i $4,38 \%$ na talijanskom tržištu.

7 Budući da se izračun uslužnog učinka izvoza uslužnog sektora visoke dodane vrijednosti temelji na izračunima stopa rasta, a podaci o izvozu uslužnog sektora visoke dodane vrijednosti zemalja članica Europske unije su raspoloživi za vremensko razdoblje od 2008. do 2012. godine, interpretacija rezultata moguća je za razdoblje od 2009. do 2012. godine. 


\section{Tablica 7.}

GEOGRAFSKI UČINAK IZVOZA USLUŽNOG SEKTORA VISOKE DODANE VRIJEDNOSTI REPUBLIKE HRVATSKE NA TRŽIŠTE EUROPSKE UNIJE, PREMA IZVOZNIM ODREDIŠTIMA, U RAZDOBLJU OD 2009. ${ }^{8}$ DO 2012. GODINE, U POSTOCIMA

\begin{tabular}{|l|r|r|r|r|}
\hline \multicolumn{1}{|c|}{ Zemlja } & $\mathbf{2 0 0 9 .}$ & $\mathbf{2 0 1 0 .}$ & $\mathbf{2 0 1 1 .}$ & \multicolumn{1}{c|}{$\mathbf{2 0 1 2 .}$} \\
\hline Slovenija & $-0,073$ & 0,002 & 0,014 & $-0,006$ \\
\hline Njemačka & $-0,006$ & $-0,044$ & $-0,049$ & $-0,053$ \\
\hline Nizozemska & 0,004 & 0,007 & 0,010 & 0,025 \\
\hline Italija & 0,002 & 0,042 & 0,022 & $-0,025$ \\
\hline Austrija & $-0,020$ & 0,028 & 0,004 & 0,003 \\
\hline Mađarska & $-0,002$ & 0,004 & 0,003 & 0,000 \\
\hline Češka & $-0,004$ & $-0,002$ & 0,015 & 0,000 \\
\hline Slovačka & 0,000 & 0,000 & 0,002 & 0,001 \\
\hline Ujedinjeno Kraljevstvo & 0,004 & $-0,010$ & 0,005 & $-0,002$ \\
\hline Švedska & 0,002 & $-0,024$ & $-0,001$ & 0,000 \\
\hline Ukupni geografski učinak & $\mathbf{- 0 , 0 9 4}$ & $\mathbf{0 , 0 0 2}$ & $\mathbf{0 , 0 2 6}$ & $\mathbf{- 0 , 0 5 7}$ \\
\hline
\end{tabular}

Izvor: izračun autora.

Učinak konkurentnosti (CE) ukazuje na sposobnost promatranog sektora i djelatnosti da poveća tržišni udio isključivo zbog rasta konkurentnosti, neovisno o uslužnoj ili geografskoj strukturi izvoza. Na temelju podataka prikazanim u tablici 8., vidljiv je manjak ukupne konkurentnosti jedino 2011. godine kod stručnih, znanstvenih i tehničkih djelatnosti (djelatnost $\mathrm{M}$ ), i to posebice na talijanskom $(-0,377 \%)$ i austrijskom tržištu $(-0,283 \%)$. U ostalim promatranim godinama zabilježen je pozitivan ukupni učinak konkurentnosti u svim djelatnostima uslužnog sektora visoke dodane vrijednosti Republike Hrvatske na tržištu Europske unije. Gledano prema pojedinim djelatnostima uslužnog sektora visoke dodane vrijednosti, pozitivan učinak konkurentnosti posebice je vidljiv u djelatnosti informacija i komunikacija (djelatnost J) na mađarskom, češkom i slovačkom tržištu; u stručnim, znanstvenim i tehničkim djelatnostima (djelatnost $\mathrm{M}$ ) na nizozemskom i talijanskom tržištu te tržištu Ujedinjenog Kraljevstva, a u administrativnim i pomoćnim uslužnim djelatnostima (djelatnost $\mathrm{N}$ ) na nizozemskom, mađarskom

8 Budući da se izračun geografskog učinka izvoza uslužnog sektora visoke dodane vrijednosti temelji na izračunima stopa rasta, a podaci o izvozu uslužnog sektora visoke dodane vrijednosti zemalja članica Europske unije su raspoloživi za vremensko razdoblje od 2008. do 2012. godine, interpretacija rezultata moguća je za razdoblje od 2009. do 2012. godine. 
i češkom tržištu. Analiziranjem ukupne konkurentnosti na pojedinim tržištima u razdoblju od 2009. do 2012. godine, metoda konstantnih tržišnih udjela ukazuje na pad učinka konkurentnosti djelatnosti J, oscilaciju učinka konkurentnosti djelatnosti $\mathrm{M}$ te znatan rast učinka konkurentnosti djelatnosti N na tržištu Europske unije.

Tablica 8 .

UČINAK KONKURENTNOSTI IZVOZA USLUŽNOG SEKTORA VISOKE DODANE VRIJEDNOSTI REPUBLIKE HRVATSKE NA TRŽIŠTE EUROPSKE UNIJE, PREMA IZVOZNIM ODREDIŠTIMA I DJELATNOSTIMA, U RAZDOBLJU OD 2009. DO 2012. GODINE, U POSTOCIMA

\begin{tabular}{|c|c|c|c|c|c|c|c|c|c|c|c|c|c|}
\hline \multirow[b]{2}{*}{$\begin{array}{l}\text { R. } \\
\text { br. }\end{array}$} & \multirow[b]{2}{*}{ Zemlja } & \multicolumn{4}{|c|}{ Djelatnost J } & \multicolumn{4}{|c|}{ Djelatnost M } & \multicolumn{4}{|c|}{ Djelatnost $\mathrm{N}$} \\
\hline & & 2009. & 2010. & 2011. & 2012. & 2009. & 2010. & 2011. & 2012. & 2009. & 2010. & 2011. & 2012. \\
\hline 1 & Slovenija & 0,428 & $-0,076$ & 0,000 & 0,001 & $-0,096$ & $-0,187$ & 0,387 & $-0,109$ & 0,017 & $-0,006$ & 0,061 & 0,080 \\
\hline 2 & Njemačka & 0,461 & $-0,259$ & 0,133 & $-0,214$ & 0,034 & $-0,062$ & 0,035 & 0,684 & 0,021 & 0,072 & $-0,155$ & 0,187 \\
\hline 3 & Nizozemska & 0,936 & $-0,256$ & 0,425 & 0,301 & $-0,051$ & 5,409 & $-0,197$ & $-0,049$ & $-0,004$ & 0,093 & $-0,009$ & 14,873 \\
\hline 4 & Italija & $-0,040$ & 0,002 & 0,097 & 0,051 & 0,054 & 3,662 & $-0,377$ & 0,188 & $-0,167$ & 0,366 & $-0,030$ & $-0,034$ \\
\hline 5 & Austrija & 0,120 & $-0,060$ & $-0,123$ & $-0,083$ & 0,237 & 0,008 & $-0,283$ & 0,346 & 0,048 & 0,108 & $-0,190$ & $-0,061$ \\
\hline 6 & Mađarska & 0,516 & 3,460 & $-0,614$ & $-0,279$ & $-0,099$ & 0,051 & $-0,124$ & $-0,096$ & $-0,006$ & 0,083 & $-0,004$ & 12,614 \\
\hline 7 & Češka & 3,550 & $-0,273$ & 0,003 & 0,264 & $-0,013$ & 0,034 & 0,274 & $-0,081$ & 1,407 & $-0,014$ & 8,191 & $-0,123$ \\
\hline 8 & Slovačka & 0,068 & 0,793 & 3,514 & 0,982 & 0,456 & 0,520 & 0,017 & 0,314 & 0,432 & 0,004 & 0,000 & $-0,011$ \\
\hline 9 & $\begin{array}{l}\text { Ujedinjeno } \\
\text { Kraljevstvo }\end{array}$ & 0,481 & $-0,102$ & 0,117 & 0,003 & 0,808 & $-0,155$ & $-0,034$ & 17,265 & 0,289 & $-0,235$ & 0,601 & $-0,050$ \\
\hline 10 & Švedska & 2,312 & $-0,029$ & 0,414 & 0,190 & $-0,044$ & $-0,099$ & 0,080 & 0,118 & $-0,095$ & 2,638 & 0,721 & $-0,385$ \\
\hline & $\begin{array}{l}\text { Ukupni učinak } \\
\text { konkurentnosti }\end{array}$ & 8,833 & 3,199 & 3,965 & 1,215 & 1,286 & 9,182 & $-0,223$ & 18,581 & 1,940 & 3,110 & 9,186 & 27,091 \\
\hline
\end{tabular}

J - Informacije i komunikacije, M - Stručne, znanstvene i tehničke djelatnosti, N-Administrativne i pomoćne uslužne djelatnosti.

Izvor: izračun autora.

Ukupni učinak (TE) mjeri promjenu izvoznog tržišnog udjela uslužnog sektora visoke dodane vrijednosti Republike Hrvatske u ukupnom izvozu Europske unije na godišnjoj razini. Sagledaju li se zajedno doprinosi uslužnog i geografskog učinka i učinka konkurentnosti na promjenu tržišnog udjela izvoza djelatnosti uslužnog sektora visoke dodane vrijednosti Republike Hrvatske na tržište Europske unije, u razdoblju od 2009. do 2012. godine, temeljem podataka prikazanih u tablici 9., može se izvesti nekoliko zaključaka: 
- u svim djelatnostima uslužnog sektora visoke dodane vrijednosti Republike Hrvatske ostvaren je pozitivan ukupni učinak (TE) promjene tržišnog udjela izvoza, što znači da izvoz svih djelatnosti uslužnog sektora visoke dodane vrijednosti Republike Hrvatske raste brže u odnosu na izvozni rast tih djelatnosti uslužnog sektora visoke dodane vrijednosti koji ostvaruje tržište Europske unije.

- najveći tržišni udio uslužnog sektora visoke dodane vrijednosti Republika Hrvatska ostvaruje u djelatnosti $\mathrm{N}(10,505 \%)$, potom u djelatnosti $\mathrm{M}$ (7,039\%), a najmanji u djelatnosti J (4,194\%), što znači da djelatnost $\mathrm{N}$ ostvaruje najbrži rast izvoza u uslužnom sektoru visoke dodane vrijednosti Republike Hrvatske.

- u svim djelatnostima uslužnog sektora visoke dodane vrijednosti Republike Hrvatske ostvaren je pozitivan učinak konkurentnosti (CE) promjene tržišnog udjela izvoza, što upućuje na konkurentske prednosti djelatnosti uslužnog sektora visoke dodane vrijednosti Republike Hrvatske u odnosu na tržište Europske unije.

- uslužni učinak (UE) promjene tržišnog udjela izvoza uslužnog sektora visoke dodane vrijednosti Republike Hrvatske oscilira tijekom promatranog razdoblja. U godinama kada je zabilježen pozitivan uslužni učinak znači da je izvoz uslužnog sektora visoke dodane vrijednosti Republike Hrvatske bio koncentriran u uslužnim djelatnostima za kojima je postojao relativno brzi rast potražnje. Suprotno vrijedi za godine u kojima je zabilježen negativan uslužni učinak.

- geografski učinak (GE) promjene tržišnog udjela izvoza uslužnog sektora visoke dodane vrijednosti Republike Hrvatske oscilira tijekom promatranog razdoblja. U 2010. i 2011. godini kada je zabilježen pozitivan geografski učinak znači da je izvoz uslužnog sektora visoke dodane vrijednosti Republike Hrvatske bio koncentriran na brzo rastuća izvozna odredišta. Suprotno vrijedi za 2009. i 2012. godinu, kada je zabilježen negativan geografski učinak.

- na tržišni udio izvoza uslužnog sektora visoke dodane vrijednosti Republike Hrvatske nepovoljno je djelovala struktura izvoza prema uslužnim djelatnostima (uslužni učinak) i izvoznim tržištima (geografski učinak), što je u znatnoj mjeri nadomjestila visoka konkurentnost (učinak konkurentnosti).

- budući da učinak konkurentnosti (CE) ostvaruje najveće pozitivne vrijednosti u usporedbi sa ostalim učincima promjene tržišnog udjela (uslužnim i geografskim učinkom), može se zaključiti da je, u promatranom razdoblju, učinak konkurentnosti u najvećoj mjeri pozitivno utjecao na promjene tržišnog udjela izvoza uslužnog sektora visoke dodane vrijednosti Republike Hrvatske na tržište Europske unije. 
Temeljem svega navedenog može se prihvatiti istraživačka hipoteza te zaključiti kako su promjene tržišnog udjela izvoza uslužnog sektora visoke dodane vrijednosti Republike Hrvatske na tržište Europske unije uzrokovane u najvećoj mjeri učinkom konkurentnosti.

Tablica 9.

DISTRIBUCIJA UČINAKA METODE KONSTANTNIH TRŽIŠNIH UDJELA ZA IZVOZ DJELATNOSTI USLUŽNOG SEKTORA VISOKE DODANE VRIJEDNOSTI REPUBLIKE HRVATSKE NA TRŽIŠTE EUROPSKE UNIJE, ZA RAZDOBLJE OD 2009. DO 2012. GODINE, U POSTOCIMA

\begin{tabular}{|l|r|r|r|r|r|}
\hline & \multicolumn{1}{|c|}{ TE } & \multicolumn{1}{c|}{ CE } & \multicolumn{1}{c|}{ UE } & \multicolumn{1}{c|}{ GE } & MIX \\
\hline DJELATNOST J & & & & & \\
\hline 2009. & 8,482 & 8,833 & $-0,016$ & $-0,094$ & $-0,242$ \\
\hline 2010. & 3,074 & 3,199 & 0,063 & 0,002 & $-0,190$ \\
\hline 2011. & 4,018 & 3,965 & $-0,025$ & 0,026 & 0,052 \\
\hline 2012. & 1,202 & 1,215 & 0,001 & $-0,057$ & 0,043 \\
\hline Prosjek & 4,194 & 4,303 & 0,006 & $-0,031$ & $-0,084$ \\
\hline & & & & & \\
\hline DJELATNOST M & & & & & \\
\hline 2009. & 1,494 & 1,286 & $-0,004$ & $-0,094$ & 0,305 \\
\hline 2010. & 9,245 & 9,182 & 0,002 & 0,002 & 0,060 \\
\hline 2011. & $-0,564$ & $-0,223$ & $-0,013$ & 0,026 & $-0,355$ \\
\hline 2012. & 17,979 & 18,581 & $-0,028$ & $-0,057$ & $-0,517$ \\
\hline prosjek & 7,039 & 7,206 & $-0,011$ & $-0,031$ & $-0,127$ \\
\hline & & & & & \\
\hline DJELATNOST N & & & & & \\
\hline 2009. & 2,018 & 1,940 & 0,027 & $-0,094$ & 0,144 \\
\hline 2010. & 3,385 & 3,110 & $-0,028$ & 0,002 & 0,301 \\
\hline 2011. & 9,637 & 9,186 & $-0,007$ & 0,026 & 0,432 \\
\hline 2012. & 26,981 & 27,091 & 0,050 & $-0,057$ & $-0,103$ \\
\hline prosjek & 10,505 & 10,332 & 0,011 & $-0,031$ & 0,193 \\
\hline
\end{tabular}

J - Informacije i komunikacije, M - Stručne, znanstvene i tehničke djelatnosti, N-Administrativne i pomoćne uslužne djelatnosti.

Izvor: izračun autora. 


\section{Zaključak}

U ovome radu po prvi puta je korištenjem metode konstantnih tržišnih udjela analiziran relativni položaj izvoza usluga visoke dodane vrijednosti Republike Hrvatske na tržište Europske unije, u razdoblju od 2008. do 2012. godine. Rezultati metode konstantnih tržišnih udjela pokazali su da je u svim djelatnostima uslužnog sektora visoke dodane vrijednosti Republike Hrvatske ostvaren pozitivan učinak konkurentnosti promjene tržišnog udjela izvoza uslužnog sektora visoke dodane vrijednosti, što upućuje na konkurentske prednosti djelatnosti uslužnog sektora visoke dodane vrijednosti Republike Hrvatske u odnosu na tržište Europske unije. Prosječni učinak konkurentnosti promjene tržišnog udjela izvoza uslužnog sektora visoke dodane vrijednosti Republike Hrvatske na tržište Europske unije je iznosio 7,28\%. Uslužni učinak promjene tržišnog udjela izvoza uslužnog sektora visoke dodane vrijednosti Republike Hrvatske oscilirao je tijekom promatranog razdoblja, a u prosjeku je iznosio $0,002 \%$. Također, geografski učinak promjene tržišnog udjela izvoza uslužnog sektora visoke dodane vrijednosti Republike Hrvatske na tržište Europske unije je oscilirao tijekom promatranog razdoblja, a u prosjeku je iznosio $-0,031 \%$. Budući da je učinak konkurentnosti ostvario najveće pozitivne vrijednosti u usporedbi sa ostalim učincima promjene tržišnog udjela izvoza uslužnog sektora visoke dodane vrijednosti (uslužnim i geografskim učinkom), može se zaključiti da je u promatranom razdoblju učinak konkurentnosti u najvećoj mjeri pozitivno utjecao na promjene tržišnog udjela izvoza uslužnog sektora visoke dodane vrijednosti Republike Hrvatske na tržište Europske unije.

Najveći tržišni udio uslužnog sektora visoke dodane vrijednosti Republika Hrvatska ostvaruje u administrativnim i pomoćnim uslužnim djelatnostima, potom u stručnim, znanstvenim i tehničkim djelatnostima, a najmanji u djelatnostima informacija i komunikacija, što znači da administrativne i pomoćne uslužne djelatnosti ostvaruju najbrži rast izvoza u uslužnom sektoru visoke dodane vrijednosti Republike Hrvatske na tržište Europske unije.

Zaključno valja istaknuti kako strukturna obilježja, a posebice naglašena konkurentnost, koja su potvrđena u ovome radu, znatno određuju perspektivu budućega rasta hrvatskog izvoza. Republika Hrvatska postala je 01. srpnja 2013. godine punopravnom članicom Europske unije, čime su se u određenoj mjeri redefinirali ne samo trgovinski odnosi sa sadašnjim zemljama članicama ove regionalne ekonomske integracije, već i sa ostalim važnim vanjskotrgovinskim partnerima izvan nje. U budućim bi se istraživanjima, stoga, trebao analizirati utjecaj integracijskih procesa na izvoz, odnosno izlaz usluga Republike Hrvatske. 
Z. LACKOVIĆ VINCEK, V. BILAS, M. BOŠNJAK: Primjena metode konstantnih tržišnih udjela na izvoz uslužnog sektora... EKONOMSKI PREGLED, 70 (3) 351-379 (2019)

\section{Literatura}

Amador, J. i Cabral, S. (2008). The Portuguese export performance in perspective: A constant market share analysis. Banco de Portugal Economic Bulletin, 201-221.

Athanasoglou, P., Backinezos, C. i Georgiou, E. (2010). Export performance, competitiveness and commodity composition. Working paper, br. 114, Bank of Greece.

Buturac, G., Lovrinčević, Ž. i Mikulić, D. (2017). International competitiveness and restructuring of the Croatian food industry. Acta Oeconomica, 67(3), 435-462.

Buturac, G., Lovrinčević, Ž. i Mikulić, D. (2014). Export Competitiveness of Croatian Textile Industry - CMS Analysis and Importance for Economy. Textil ve Konfeksiyon, 24(2), 158-168.

Cabral, S. (2004). Recent evolution of Portuguese export market shares in the European Union. Banco de Portugal Economic Bulletin, str. 79-91.

Ćudina, A., Lukinić Čardić, G. i Sušić, G. (2012). Analiza relativnog položaja hrvatskog izvoza na tržištu Europske unije. Ekonomski pregled, 63(5-6), 291-321. Dostupno na https://hrcak.srce.hr/index.php?show=clanak\&id_clanak_jezik=126841

Deutsche Bundesbank (2006). Germany in the Globalisation Process. Monthly Report, prosinac 2006.

Državni zavod za statistiku (2013). Strukturne poslovne statistike, Zagreb: Državni zavod za statistiku.

European Central Bank (2005). Competitiveness and the export performance of the euro area. Occasional Paper Series 30, Task Force of the Monetary Policy Committee of the European System of Central Banks.

Europska komisija (2015). Single Market Strategy. Upgrading the Single Market: more opportunities for people and business. Bruxelles: European Commission.

Eurostat (2016a). Structural business statistics [online]. Dostupno na http:// ec.europa.eu/eurostat/web/structural-business-statistics [20. travnja 2016. godine].

Eurostat (2016b). Trade by NACE Rev. 2 activity and enterprise size class [online]. Dostupno na http://appsso.eurostat.ec.europa.eu/nui/submitViewTableAction.do [29. rujna 2016. godine]

Eurostat (2018). Trade by NACE Rev. 2 activity and enterprise size class [online]. Dostupno na http://appsso.eurostat.ec.europa.eu/nui/show.do?dataset=ext_ tec01\&lang=en [26. kolovoza 2018. godine]. 
Finicelli, A., Sbracia, M. i Zaghini, A. (2011). A disaggregated analysis of the export performance of some industrial and emerging countries. International Economics and Economic Policy, 8(1), 93-113.

Foresti, G. (2004). An attempt to explain the Italian export market share dynamics during the nineties. Centro studi Confindustria Working Paper, br. 47.

Gilbert, J., Muchová, E. (2018). Export competitiveness of Central and Eastern Europe since the enlargement of the EU. International Review of Economics and Finance, 55, 78-85.

Hrvatska narodna banka (2015). Razmjena usluga s inozemstvom. Zagreb: Hrvatska narodna banka.

International Trade Center (2015). List of exports for the services [online]. Dostupno na http://www.trademap.org/Country_SelService_TS.aspx [11. veljače 2017.].

Jiménez, N. i Martín, E. (2010). A constant market share analysis of the Euro Area in the period 1994-2007, Economic Bulletin.

Madan, S. i Sharma, R. (2018). Trade Competitiveness of Indian Wheat during Post-Reform Period. Asian Review of Social Sciences, 7(1), 25-35.

Michel, B. (2005). Trends in export market shares between 1991 and 2001. Working Paper. br. 7-05, Federal Planning Bureau, Brussels.

Milana, C. (1988). Constant Market Share Analysis and Index Number Theory. European Journal of Political Economy, 4(4), 453-478.

Richardson, J. (1971a). Constant market share analysis of export grpwth. Journal of International Economics, 1, 227-239.

Richardson, J. (1971b). Some sensitivity tests for a constant market share analysis of export growth. Review of Economics and Statistics, 53(3), 301-304.

Simonis, D. (2000). Belgium's export performance: a constant market shares analysis. Working Paper, br. 2, Federal Planning Bureau, Brussels.

Skriner, E. (2009). Competitiveness and specialisation of the Austrian export sector: A constant-market-shares analysis. Institut für Höhere Studien (IHS), Vienna, Economics Series, br. 235.

Tyczynski, H. (1951). World trade in manufactured commodities 1899-1959. The Manchester School of Economic and Social Studies, 19, 222-304.

United Nations Conference on Trade and Development (2015). Goods and Services: Exports and Imports of Goods and Services, annual [online]. Dostupno na http://unctadstat.unctad.org/wds/TableViewer/tableView.aspx [11. rujna 2015.]. 


\title{
APPLICATION OF THE CONSTANT MARKET SHARE METHOD ON THE HIGH VALUE ADDED SERVICES SECTOR EXPORT OF THE REPUBLIC OF CROATIA TO THE EUROPEAN UNION MARKET
}

\begin{abstract}
Summary
The subject of the analysis in this paper is relative change of high value added services sector export of the Republic of Croatia to the European Union market in the period from 2008 to 2012 by applying constant market share method that enables determination of changes of certain countries market share. The change of market share is decomposed into structural effect which indicates how much market share is affected by the export structure according to certain services (service orientation), i.e. export markets (geographical orientation) and the competitiveness effect which consists of all other factors that may have impact on competitiveness of services on certain market and consequentially their market share. The results of conducted research indicate that increase of Croatian high value added services sector export to the European Union market in the period 20082012 is primarily the consequence of competitiveness effect.
\end{abstract}

Keywords: export, services, value added, constant market share method 